\title{
Social-Economic Empowerment through Integration of Social Finance and Business of Pesantren In East Java
}

\author{
Nurlaili Adkhi Rizfa Faiza ${ }^{1 *}$ \\ ${ }^{1}$ Islamic Economics and Business Faculty, IAIN Kediri
}

\begin{abstract}
The large number of Pesantren and the influence of their alumni indicate that there is enormous potential for Pesantren in participating in social change and as agents of economic empowerment for communities in the surrounding area. In East Java, the development of the Pesantren business has begun to become a special focus with the existence of the Pesantren business holding (HEBITREN), One Pesantren One Product (OPOP), and Pesantren Sarekat Business Cooperative (KSBP) as part of the Pesantren independence development program. In addition, Pesantren also manage Islamic social finance such as Amil ZIS Institution (LAZIS) and Micro Waqf Banks (BWM) that can empower the economy of the surrounding community. The approach of this research used qualitative study of the library by using scientific research of both articles, journals, as well as related agency data. This study aims to provide a synthesis of attempts to develop an alternative model of community economic empowerment through the integration of social finance and business run by Pesantren in East Java, with the goal of maximizing the independence and quality of Pesantren education, which contributes to the ummah's and nation's economic independence.
\end{abstract}

\section{Introduction}

Pesantren, or known as Islamic Boarding School, is a one-of-a-kind gem in Indonesia, and it plays an important role in the nation's history. Pesantren's teaching and learning approach is unique in that it combines Islamic beliefs with local and Western wisdom methods. In the history of the Indonesian country's struggle, Pesantren have produced leading combatants in the fight against colonialism, as well as cadres of the people and the nation who have influenced society.

The contemporary social situation presents a new challenge for Pesantren in dealing with global competitiveness without having to abandon the social value system that Pesantren has created since the XVIII to XX centuries. (Wahid, 1995), as the capital of Islamic economic development in numerous Pesantren in East Java, as core beliefs and core values derived from traditional Islamic boarding school values. In that perspective, Azyumardi Azra (Azra,

\footnotetext{
* Corresponding author: rizfafaiza@iainkediri.ac.id
} 


\section{$A I \bar{C} \quad$ Annual International Conference \\ on Islamic Economics and Business, 2021}

2004) explained that the role of Pesantren is not only to play its traditional function as transmission of Islamic knowledge, maintenance of Islamic traditions, and develop scholars, but how the role of Pesantren is also expected to be a center for health education, development of appropriate technology, environmental conservation and more importantly as a center for empowerment in global economy. Therefore, the function of Pesantren is not only as a center of cadre of religious thinkers (center of excellence) which only focuses on developing human resources (human resources), but the function of Pesantren is expected to be an institution of social empowerment (agent of development) in the economic field in accordance with the current social condition (Faozan, 2011).

Pesantren have a lot of potential to play a bigger role in the future, not only as keepers of community piety values and centers for the spread of Islam in rural areas, but also as a counter part to the Indonesian government's development (Nugroho, 2017). The establishment of a Pesantren in an area makes the Pesantren have a strategic role that can make the area more developed. Since the 1970s, Pesantren have played many strategic roles. The strategic role of Pesantren includes roles in the economic, social and political fields (U Lugina, 2018). New entrepreneurs emerging from Islamic boarding schools will have a good impact on people's lives in general, as they will help to eliminate unemployment and poverty in Indonesia. (Misjaya et al., 2019).

There are two reasons why Pesantren can become the pioneers of the people's economy. First, santri are a group of people who are highly committed to their religion. The commitment of the students in their religion can affect the economic activities carried out by the students. Second, by focusing Pesantren activities on Islamic studies, it can work as a catalyst for sharia economics in society and support the development of young entrepreneurs with an Islamic mindset. (Muttaqin, 2016).

The potential demand for consumption and production of halal products in the Pesantren environment also provides promising economic opportunities. Pesantren has become one of the agents of change in society, not least in East Java. According to data from the Ministry of Religion, there are at least 4452 Pesantrens (Kemenag, 2021) in East Java. The majority of these have agricultural or agribusiness potential, farm, trade, industries, and financial institutions. Pesantren, in this context, are not just concerned with religion and education; they are also a vital part of the social movement, overseeing various local economic programs in order to alleviate poverty and economic disparity in the face of social realities. This perspective is expected to serve as the conceptual and practical foundation for the establishment of a people's economy Pesantren in East Java, based on local wisdom values.

In order to enhance the Islamic economy and finance as a new source of growth, enhancing the economic independence of Pesantrens becomes a key factor. Pesantren are now used not just as a religiously centered educational institution, but also as a place for santri and the surrounding community to acquire socio-economic empowerment. Pesantren is also a community node that has a huge presence in terms of mobilizing the community to support the Islamic economy and finance.

This aim of the research synthesizes between the social finance that obtained and processed by the Pesantren and the Pesantren business so that the Pesantren does not only have economic independence, but is also able to produce quality education which contributes to the ummah's and the nation's economic independence, in contrast to other researches that only discuss the empowerment of Pesantren through one source of funds, only it's business or it's social finance. The integration model between social finance and Pesantren business that has been carried out by Pesantren in East Java is expected to be replicated by other Pesantren so that they are able to increase the independence and quality of education that contributes to the economic independence of the people and the nation. 


\section{Research Methods}

The approach of this research used qualitative study of the library by using scientific research of both articles, journals, as well as related agency data. This research focussing to built a model that synthesizing social finance and business of Pesantren in East Java so that can produce quality education and economic independent which contributes to the ummah's and the nation's economic independence.

\section{Pesantren and Social Economic Development}

Refers to the theory of functionalism that sees society as a system of several interconnected parts, one part cannot be understood apart from the whole, thus, in the perspective of functionalism there are several functional requirements or needs that must be met in order for a social system to survive (Turama, 2018), Pesantren that stand in the midst of society certainly also provide welfare for the surrounding community. Where there is a Pesantren, the economy will definitely live, at least serving the needs of students, whether living or commuting, whether salaf, modern or boarding school.

Pesantren, without being intended as an economic community, has become a distinct community. Is it the Pesantren community, the alumni, or the parent community of the santri, which can be used as an economic activity. The thing that needs to be encouraged from the Pesantren world itself is the skills in the Pesantren, how to map the potential of the Pesantren, whether it is based on finance, industry, services, agriculture, business opportunities, and even santri education. In terms of business opportunities, for example, local residents can sell in the Pesantren environment. This is especially promising if the product being sold is something that students really need. Pesantren can also establish business entities such as cooperation that can help the people's economy by lending money to the community for business capital or the surrounding community who will entrust their products to the cooperation..

The economic empowerment of the Pesantren-based community is an effective and necessary way to reduce poverty. This empowerment can be done while preaching, in addition to welfare, it also aims to educate the community.

Optimizing all the resources owned by Pesantren can create a great power in the economy if managed properly. In terms of assets, for example, Pesantren can take advantage of the vast land they have to use for farming activities. Workers from these farming activities could be students who are carried out alternately or it could be by employing the community around the Pesantren as farmers who manage the land. The harvests obtained can be sold to finance the operational activities of the Pesantren. In addition, Pesantren can also take advantage of other assets they have for the economic sector. Utilization of these assets must be accompanied by good asset management from the Pesantren so that asset utilization can take place optimally. Furthermore, in terms of human resources, the students can be equipped with skills for entrepreneurship so that the Pesantren can have a business entity that can support the economic activities of the students and the community. (Solihin \& Adnan, 2020).

There are many Pesantrens that have formed Kelompok Wirausaha Bersama (KWUB) between Pesantren as well as between Pesantren and the community. In addition, there is also the establishment of the Forum Komunikasi Pengembangan Ekonomi Kerakyatan (FKPEK) although this institution is still in the early stages of being established (Ugin Lugina et al., 2018). In support of enrepreneurship skills, Pesantren can provide creativity to their 


\section{$A I C \overline{I E B} \quad$ Annual International Conference \\ on Islamic Economics and Business, 2021}

students so that they can create a creative product to sell or a tool that will contribute to the community around the Pesantren with their work..

The economic potential of Pesantren can be better if the Pesantren can establish a cooperative or Baitul Maal Wattamwil (BMT). Cooperatives and BMTs are members of the type of Islamic microfinance institution (LKMS). The roles of LKMS in society and Pesantren are: (1) Bringing and introducing to the community the practice of sharia economics. Through socialization to the community, LKMS can be an effective means to advance the economy of the Pesantren as well as to educate the public. (2) To provide guidance and funding for MSMEs established by the community. This role can make the economy more passionate because people who lack venture capital can obtain capital as well as business development from this LKMS. (3) Release the community's dependence on moneylenders. People can breathe easier because gradually they are no longer dependent on moneylenders who always charge high interest rates and hinder people's economic growth. (4) Maintaining economic justice. Economic justice can be created more because LKMS has equal distribution of funds and does not take sides with certain groups (Alhifni, 2018).

\section{Development of Social Finance and Business of Pesantren In East Java}

Pesantrens play a vital role in mobilizing all available resources in the field of education to respond to community developments since Pesantrens have significant potential and prospects for this. Many factors exist in Pesantrens that can help to encourage community development. Kyai's charisma, which is well-known in the community, his independence, and his position in the community are among them. As a result, Pesantrens are well suited to efficiently fulfilling the role of empowerment and community transformation. (Maghfur, 2019).

On the website of the Directorate General of PD Pontren of the Ministry of Religion, the economic and business activities carried out by Pesantrens are generally in the following eleven areas, namely: (1) maritime; (2) agribusiness; (3) vocational; (4) Cooperatives, SMEs, Sharia Economics; (5) Livestock; (6) plantations; (7) Technology; (8) Health center; (9) sports; (10) cultural arts; (11) and others.

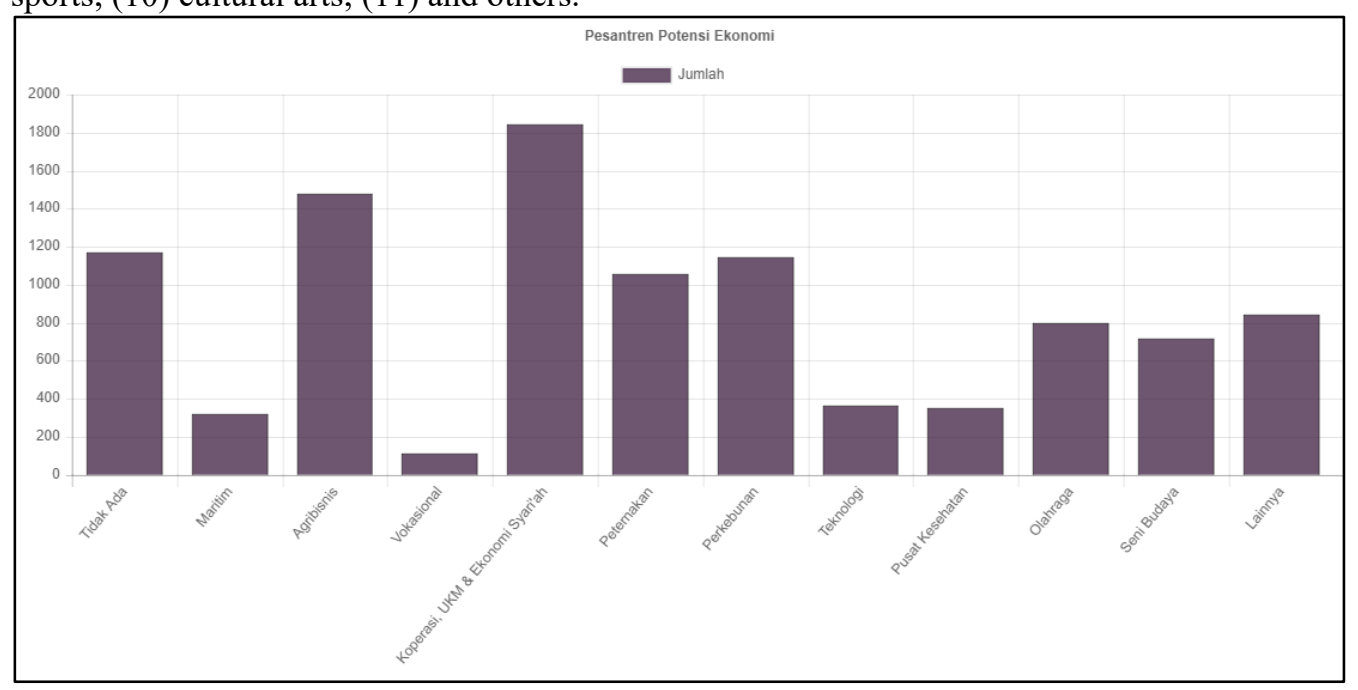

Fig.1. Pesantren economic potential 


\section{$A I \bar{C} \quad$ Annual International Conference \\ on Islamic Economics and Business, 2021}

In a presentation by Bank Indonesia at ISEF 2021, stated that the business characteristics of Pesantren in Indonesia are as follows: (1) West Java: There are many Pesantrens in Indonesia but the average number of santri in each Pesantren is still below East Java, the majority are in business, and some have become independent; (2) Central Java: The average Pesantren has a business but has not been managed optimally. Business exists but is not yet large; (3) East Java: East Java as an old and patron Pesantren in Indonesia has the second largest Pesantrens after West Java with the highest number of stayed students and the average total number of students in each Pesantren. Business is starting to be organized because East Java has carried out capacity building for the economic acceleration of Pesantren. In addition, Pesantren in East Java have also begun to form regional holdings; (4) Sumatra: Pesantrens in Sumatra have led to the establishment of an entrepreneurial ecosystem, especially the utilization of plantation potential; (5) Eastern Indonesia: Pesantrens are starting to have a high entrepreneurial spirit, and already have an entrepreneurial ecosystem. This Pesantrens in Eastern Indonesia has great economic potential but has not been utilized in the form of a Pesantren business.

In East Java, Pesantren Riyadhul Jannah Pacet, Mojokerto has a role in empowering the community. The role of Pesanrens in empowering the community's economy through its business units ((Lazuardian \& Zaki, 2020). Pesantren Darul Ulum Banyuanyar Pamekasan is another Pesantren that has achieved economic independence by expanding shopping businesses, commodities production, service, and financial industries, (Hariyanto, 2017) and business development through alumni network (Jannah, 2019).

Pesantren Sidogiri Pasuruan implements social entrepreneurship, by innovating the formation of internally owned social entrepreneurship institutions such as the Kopontren Sidogiri, Pustaka Sidogiri and Buletin Sidogiri, as well as externally owned institutions such as BMT Maslahah, BMT UGT Sidogiri, BPRS UMMU Sidogiri and the Sidogiri Agro Cooperative founded by the Pesantren Sidogiri Pasuruan civil society with the motto of khidmatan lil ma'at wa khidmatan lil ummat through the mission wants to contribute in terms of realizing baldatun thoyyibbatun wa rabbun ghafur by building qoryah thoyyibbah whose targets are education, economy and social so that it is expected to help reduce poverty and unemployment (Reginald \& Mawardi, 2015).

Other Pesantren that have business are Pesantren Al-Fitrah Surabaya with buying and selling shops; Pesantren Miftachussunnah with financial institutions (cooperatives, BMT, BPRS, LAZISWAF); Pesantren Qomaruddin with mini market, cooperative, agriculture, and travel businesses; Pesantren Sunan Drajat with businesses in mining, processing industry, and trading; Pesantren Langitan in the trade sector; Pesantren An Nur 1 and 2 in trade and cooperatives; Pesantren Lirboyo in the trade sector; Pesantren Tebuireng in Finance and Agriculture; Pesantren Bahrul Ulum in the field of trade; Pesantren Nurul Jadid in agriculture, industry, processing, trade, and finance (Cooperatives, BMT, BPRS, Laziswaf); Pesantren Gontor in agriculture and processing industry; Pesantren Salafiyah Syafiiyah in the fields of trade, agriculture, and finance; Pesantren Al Amin in the trade sector; and Pesantren An-Nuqoyyah in the processing and financial industries (Ryandono, 2018).

The East Java government has also supported the development of Pesantren businesses by establishing the One Pesantren One Product (OPOP) program, which is a Pesantren economic empowerment program that provides OPOP participants with entrepreneurship training, capital, packaging design, and the development of an online platform. OPOP is built on three fundamental pillars: (1) santripreneur, a santri empowerment program aimed at improving students' understanding and skills in creating unique sharia-compliant products that are focused toward benefit and profit; (2) Pesantrenpreneur, the Pesantren economic empowerment program through the Pondok Pesantren Cooperative which aims to produce superior halal products that can be accepted by local, national and international markets; and (3) sociopreneur, an empowerment program for Pesantren alumni that is synergized with the 


\section{$A I C \overline{I E B} \quad$ Annual International Conference \\ on Islamic Economics and Business, 2021}

community. Empowerment is carried out with a variety of social innovations, based on digital technology and creativity inclusively.

Furthermore, several Pesantrens are also incorporated in the Pesantren Business Holding (Hebitren), which is the Pesantren Business Economic Association. In collaboration with Bank Indonesia, Hebitren launched a Distribution Center (DC) in three Pesantrens in East Java. These include the Pesantren Sunan Drajat Lamongan, Pesantren Bahrul Ulum Jombang, and Pesantren Nurul Jadid Probolinggo (Republika, 2021). It is hoped that Hebitren can encourage efforts to develop an independent and highly competitive Pesantren business and economic sector by empowering the potential and network of Pesantrens that are widespread, especially in East Java.

The development of productive waqf is also the concentration of Pesantren in East Java in achieving independence. Pesantren Tebuireng Jombang has managed productive waqf so that it becomes a contributor to funds to make Pesantren more independent in development. Productive waqf units managed by the Hasyim Asyari Foundation are the source of income for $90 \%$ of Pesantren. Only $10 \%$ of income from outside the Pesantren such as assistance from the government and from the private sector. Thus, Pesantren Tebuireng relies heavily on productive waqf as a means to be economically independent (Wijaya \& Sukmana, 2019).

Same as Pesantren Tebuireng, Pesantren Gontor Ponorogo also manages productive waqf and provides many contributions both internally and externally. The collected waqf funds are managed properly and professionally so that the distribution can also be dialogical, meaning that the waqf funds are distributed productively with the development of several business fields at the Pesantren Gontor. In addition, the interesting thing is that the application of productive waqf also has implications for the five-term period of Pesantren Gontor, especially in the field of education and teaching. Facilities are growing, giving a big impact in improving the quality of education that is getting better. Not only that, productive waqf funds also contribute to the economy of the surrounding community (Fasa, 2016; Faiza, 2019). This shows that Pesantren in East Java are able to collaborate on social finance and Pesantren business for economic independence.

\section{Socio-Economic Empowerment Model Through Integration of Social Finance and Business of Pesantren}

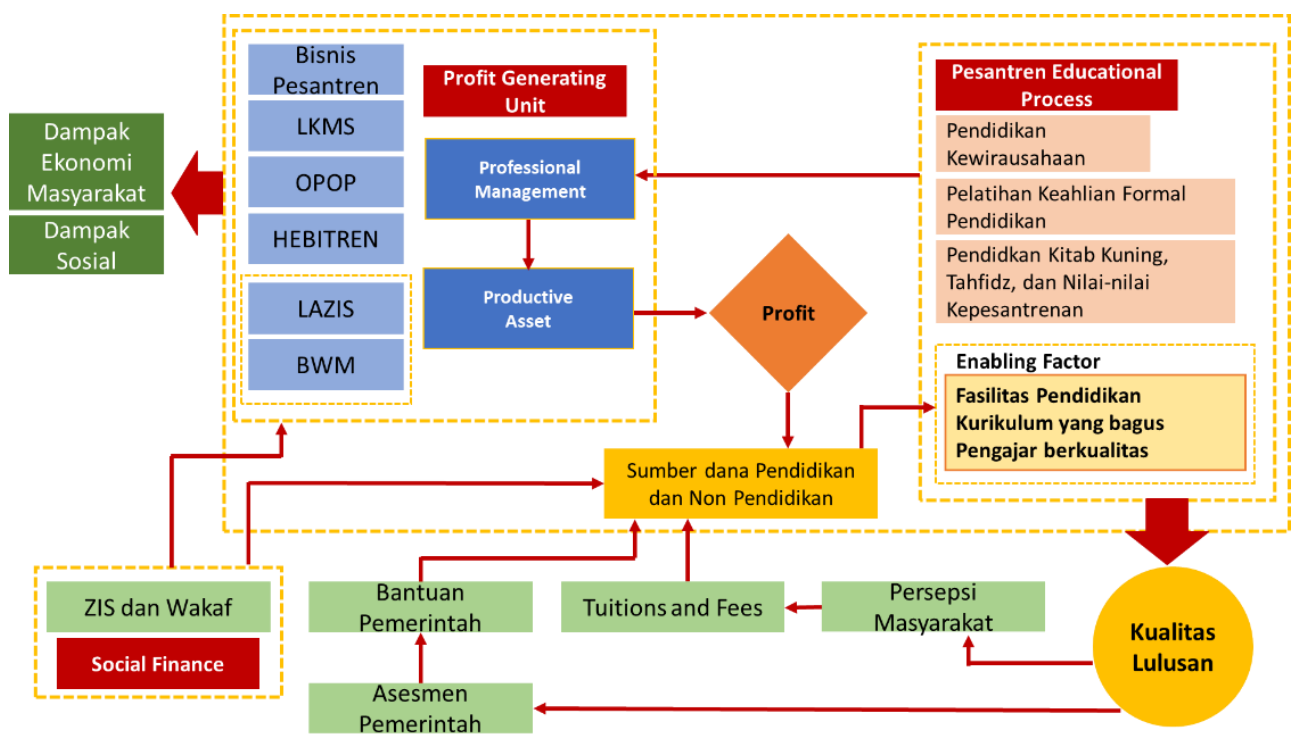




\section{$A I C \bar{C} \quad$ Annual International Conference \\ on Islamic Economics and Business, 2021}

Fig 2. Socio-Economic Empowerment Model Through Integration of Social Finance and Business of Pesantren

In the model above, there are three main pillars that play a role in socio-economic empowerment: social finance, profit generating units, and Pesantren educational processes. First, is the integration between social finance and Pesantren business (profit generating unit). The social finance collected by the Pesantren will be utilized through LAZIS, BWM, and the Pesantren business unit. First, ZIS will be utilized directly by LAZIS by distributing it to people in need. Second, waqf will be channeled through BWM for the community and through business units for the development of waqf assets so that the benefits of waqf can be replayed in business development for Pesantrens operational funding (such as the construction of educational facilities from waqf benefits). Indeed, waqf can be used for the construction/funding of educational facilities, but it will be more developed if it is empowered first through business units. As this is applied by Pesantren Tebuireng (Wijaya \& Sukmana, 2019) and Gontor (Fasa, 2016).

The independence of Pesantren in this model is developed through profit generating units by utilizing productive assets for Pesantren business activities, both in the form of Islamic Microfinance Institutions (LKMS), productive businesses, as well as government-supported business programs such as One Pesantren One Product (OPOP) and Pesantren Business Holding (HEBITREN). The development of this profit generating unit must be supported by professional management obtained from the santri education process through the Pesantren educational process including entrepreneurship education, formal education skills training, and education in the kitab kuning, tahfidz, and Pesantrens values. With good management, the Pesantren business will be able to generate profits as a source of Pesantrens operational funds to support the enabler factor, namely the provision of teaching facilities, good curriculum, and quality teachers so that they can produce quality graduates.

From this model, it is expected to produce an external impact from the integration of social finance and Pesantren business, the socio-economic impact of the community. First, with the existence of a Pesantren business, it can become a job opportunity for the surrounding community. In addition, the potential demand for consumption and production of halal products in the Pesantren environment also provides promising economic opportunities for the surrounding community.

Second, the establishment of business entities and Islamic financial institution. Pesantren can establish business entities in the form of cooperatives or establish LKMS such as BMT, Micro Waqf Bank (BWM) or social institutions such as zakat institutions. These three institutions have the main function of helping the economy of the Pesantren community. Cooperatives can help the community's economy by providing loans to the community for business capital. In addition, people who have produced products can entrust their products to be sold in Pesantren cooperatives. Then BMT or BWM can also provide loans to the community for business capital. Especially for BMT, the public can also put their funds in the form of savings. Then for zakat institutions, people can channel their zakat funds through this institution. Furthermore, the zakat institution distributes the zakat it receives to people in need. The establishment of these three institutions is also in accordance with empowerment propaganda because these three institutions operate under the sharia system. As we know that many Indonesian people are unfamiliar with institutions that operate on the sharia system. The presence of these three institutions indirectly provides education to the public about sharia financial institutions and the sharia system. It is hoped that the community will be further away from the usury system so as to create a blessed and fair community economy.

Third, Pesantren can become business incubators for students with entrepreneurship education and from their experience in managing the Pesantren business. The educational process is carried out by maximizing the potential of students in the diniyah aspect, 


\section{$A I \bar{C} \quad$ Annual International Conference \\ on Islamic Economics and Business, 2021}

understanding ini Pesantren curriculum. In addition, they are also required to be maximal in the aspect of entrepreneurship so that they are able to be economically (financial) independent. The development of entrepreneurship in the Pesantren environment has become a needs or a necessity, especially if it is associated with Pesantren education which prioritizes independence, hard work, discipline and honesty. (Hariyanto, 2017). All the educational values developed by the Pesantren are the soul of entrepreneurship. With this entrepreneurial spirit will give birth to various types of creative businesses that are in accordance with local potential and resources, so that the economic independence of students will be realized. This is the basic capital produced by Pesantren in order to strengthen the community's economy in facing the global market.

Rather than all of that, the key success factors for the implementation of the Pesantren empowerment program are, among others, the implementation of good Pesantren business governance. In this case, in the Pesantren business empowerment strategy, it is necessary to ensure the availability of adequate Standard Operating Procedures (SOP), as well as a program to strengthen the management of work programs, human resources, budgets and recording of financial statements of Pesantren. In addition, the Pesantren business sector needs to be directed to focus on productive economic potential in accordance with its internal needs and take into account the characteristics of the region, and businesses that have been pioneered previously. Third, Pesantrens need to be encouraged to collaborate with each other in developing joint market integration and access, among others through the use of HEBITREN and OPOP networks.

If referring to the pattern of local wisdom, the management of the Pesantren needs to understand the internal conditions of the Pesantren and the local community so that they are able to synergize the business to be established with the potential of the surrounding community. The existence of support and involvement of the community in the economic development of the Pesantren will certainly be a strong social fortress to maintain the existence of the Pesantren. For example, the community is involved to become workers or even one of the investors in the development of the Pesantren's economic business. The model for the involvement of Pesantren stakeholders in the Pesantren's economic development efforts can be through relevant channels, for example, aspects of capital (as investors or depositors), operational aspects (as staff/employees in business units), managerial aspects (as part of management), distribution aspects (as part of management), and distribution aspects (as part of management). sales agent/product marketing), and supervisory aspect (as management and/or sharia supervisory board).

Moreover, the economic development of Pesantren based on local wisdom needs to pay attention to the conditions of existing stakeholders and are involved in every Pesantren activity so that there is good synergy between internal and external stakeholders of the Pesantren. The opportunities for the economic development of Pesantren are very broad because Pesantren are the basis of cultural power that integrates with the community so that economic development will have economic and social impacts for Pesantren. However, Pesantrens face challenges, especially if stakeholders are not ready to accept changes, especially economic development that does not pay attention to the surrounding environment which can trigger potential conflicts if not observed. Therefore, the management of Pesantren as the main motor of the economy needs to formulate a development strategy by always paying attention to the internal capabilities of the Pesantren and the development of the surrounding community (Azizah \& Fitriyani, 2018).

Finally, it is hoped that with this model, other Pesantrens will carry out (1) programs to improve the quality of Pesantren business management along with increasing the economic capacity of Pesantren in optimizing Pesantren assets, (2) helping to improve the realization of good governance with a distinctive culture and culture in the Pesantren environment. , (3) assisting the realization of high-quality Islamic human resources who play an active role in 


\section{$A \overline{I E B} \quad$ Annual International Conference \\ on Islamic Economics and Business, 2021}

and contribute to economic and social life; and (4) explore the business potential of Pesantren and regulate supply chain management to create a business ecosystem that is integrated with one another in an effort to realize socio-economic empowerment both internally and externally.

\section{Conclusion}

Pesantren has great potential to continue to play its role more broadly, not only as a center for cadre of religious thinkers (center of excellence) which only focuses on producing human resources (human resources), but the function of Pesantren is expected to be an institution of socio-economic empowerment. The integration model between social finance and Pesantren business that has been carried out by Pesantren in East Java is expected to be replicated by other Pesantren so that they are able to increase the independence and quality of education that contributes to the economic independence of the people and the nation. Finally, this research is expected to contribute to the research treasures of Pesantren and create new concepts related to the development of Pesantren in Indonesia.

\section{References}

Alhifni, A. (2018). Model Pemberdayaan Ekonomi Terpadu Pondok Pesantren Pedesaan Melalui Lembaga Keuangan Mikro Syariah. repository.unair.ac.id. http://repository.unair.ac.id/77380/

Azizah, S. N., \& Fitriyani, Y. (2018). Model pengembangan ekonomi Pesantren berbasis kearifan lokal: studi kasus Ponpes Sidogiri. Proceeding of Conference on Islamic .... https://journal.uii.ac.id/CIMAE/article/view/11936

Azra, A. (2004). Jaringan ulama: Timur Tengah dan kepulauan Nusantara abad XVII \& XVIII: akar pembaruan Islam Indonesia. Kencana.

Faiza, N. A. R. (2019). Cash Waqf Linked Sukuk sebagai Pembiayaan Pemulihan Bencana Alam Di Indonesia. In Skripsi: UIN Sunan Ampel Surabaya. http://digilib.uinsby.ac.id/id/eprint/33325

Faozan, A. (2011). Pondok Pesantren dan Pemberdayaan Ekonomi. 4.

Fasa, M. I. (2016). Model Pengembangan Wakaf Produktif Pondok Modern Darussalam Gontor Ponorogo. December 2014.

Hariyanto, R. (2017). Menumbuhkan Semangat Wirausaha Menuju Kemandirian Ekonomi Umat Berbasis Pesantren (Studi Kasus Di PP Darul Ulum Banyuanyar Pamekasan). NUANSA: Jurnal Penelitian Ilmu Sosial Dan Keagamaan Islam, 14(1), 185. https://doi.org/10.19105/nuansa.v14i1.1318

Jannah, M. (2019). ... Pembudayaan Entrepreneurship dalam Membangun Bisnis Pesantren Berbasis Alumni Network Forum (Studi Kasus Pondok Pesantren Darul Ulum Banyuanyar .... digilib.iain-jember.ac.id. http://digilib.iain-jember.ac.id/1891/

Lazuardian, R., \& Zaki, I. (2020). Kontribusi Pondok Pesantren Riyadhul Jannah Dalam Memberdayakan Ekonomi Masyarakat Desa Pacet Mojokerto. Jurnal Ekonomi Syariah Teori Dan Terapan, 7(3), 472. https://doi.org/10.20473/vol7iss20203pp472485

Lugina, U. (2018). Pengembangan Ekonomi Pondok Pesantren di Jawa Barat. In Risâlah, Jurnal Pendidikan dan Studi Islam. jurnal.faiunwir.ac.id. https://www.jurnal.faiunwir.ac.id/index.php/Jurnal_Risalah/article/download/48/89

Lugina, Ugin, Sma, P. P., \& Kuningan, K. (2018). Pengembangan Ekonomi Pondok Pesantren Di Jawa Barat. Risâlah, Jurnal Pendidikan Dan Studi Islam, 4(1, March), 


\section{$A I C \overline{I E B} \quad$ Annual International Conference \\ on Islamic Economics and Business, 2021}

53-64. https://doi.org/10.5281/zenodo.3552005

Maghfur, A. (2019). Kemandirian Santri dalam Mengelola dan Mengembangkan Perekonomian Pesantren: Studi Kasus Pondok Pesantren Fathul Ulum Kwagean Krenceng Kepung .... digilib.uinsby.ac.id. http://digilib.uinsby.ac.id/id/eprint/34560

Misjaya, M., Bukhori, D. S., Husaini, A., \& Syafri, U. A. (2019). Konsep Pendidikan Kemandirian Ekonomi Di Pondok Pesantren Mukmin Mandiri Sidoarjo - Jawa Timur. Edukasi Islami: Jurnal Pendidikan Islam, 8(01), 91. https://doi.org/10.30868/ei.v8i01.371

Muttaqin, R. (2016). Kemandirian dan pemberdayaan ekonomi berbasis Pesantren (studi atas peran Pondok Pesantren Al-ittifaq Kecamatan Rancabali Kabupaten Bandung terhadap .... JESI (Jurnal Ekonomi Syariah Indonesia). https://ejournal.almaata.ac.id/index.php/JESI/article/view/134

Nugroho, T. (2017). Reorientasi Peranan Pesantren Pada Era Pembangunan Menuju Partisipasi Pemberdayaan Masyarakat Bawah. Ulumuddin: Jurnal Ilmu-Ilmu Keislaman, 7(2), 147-155. https://doi.org/10.47200/ulumuddin.v7i2.197

Reginald, A. R., \& Mawardi, I. (2015). Kewirausahaan Sosial Pada Pondok Pesantren Sidogiri Pasuruan. Jurnal Ekonomi Syariah Teori Dan Terapan, 1(5), 333. https://doi.org/10.20473/vol1iss20145pp333-345

Ryandono, M. N. H. (2018). Peran Pondok Pesantren dalam Pemberdayaan Sosial Ekonomi di Jawa Timur pada Abad ke-20. Mozaik Humaniora, 18(2), 189-204.

Solihin, S., \& Adnan, A. (2020). Model Penyampaian Pelatihan Bisnis Online pada Masyarakat Desa dengan Kolaborasi Perguruan Tinggi dan Pesantren. TEMALI: Jurnal Pembangunan

Sosial. http://journal.uinsgd.ac.id/index.php/temali/article/view/7484

Turama, A. R. (2018). Formulasi Teori Fungsionalisme Struktural Talcott Parsons Akhmad. Jurnal Univeristas Sriwijaya, 58-69.

Wahid, A. (1995). Pesantren sebagai Subkultur. Pesantren Dan Pembaharuan, Jakarta: LP3ES.

Wijaya, M. W., \& Sukmana, R. (2019). Peran Wakaf Produktif Dalam Pemberdayaan Kemandirian Ekonomi Pondok Pesantren (Studi kasus Pesantren Tebuireng Yayasan Hasyim Asyari Jombang). In Jurnal Ekonomi Syariah Teori dan .... scholar.archive.org.

https://scholar.archive.org/work/4uwct4ncqrazxipso4uunhzjwq/access/wayback/http s://e-journal.unair.ac.id/JESTT/article/download/12841/Muhammad Widyarta Wijaya 